University of Nebraska - Lincoln

DigitalCommons@University of Nebraska - Lincoln

USDA National Wildlife Research Center - Staff Publications
U.S. Department of Agriculture: Animal and Plant Health Inspection Service

January 2007

\title{
Evaluation of two perch deterrents for starlings, blackbirds, and pigeons
}

Thomas W. Seamans

USDA/APHIS/WS National Wildlife Research Center, thomas.w.seamans@aphis.usda.gov

Scott C. Barras

United States Department of Agriculture, Animal Plant Health Inspection Service, Wildlife Services, National Wildlife Research Center

Glen E. Bernhardt

United States Department of Agriculture, Animal Plant Health Inspection Service, Wildlife Services, National Wildlife Research Center

Follow this and additional works at: https://digitalcommons.unl.edu/icwdm_usdanwrc

Part of the Environmental Sciences Commons

Seamans, Thomas W.; Barras, Scott C.; and Bernhardt, Glen E., "Evaluation of two perch deterrents for starlings, blackbirds, and pigeons" (2007). USDA National Wildlife Research Center - Staff Publications. 409.

https://digitalcommons.unl.edu/icwdm_usdanwrc/409

This Article is brought to you for free and open access by the U.S. Department of Agriculture: Animal and Plant Health Inspection Service at DigitalCommons@University of Nebraska - Lincoln. It has been accepted for inclusion in USDA National Wildlife Research Center - Staff Publications by an authorized administrator of DigitalCommons@University of Nebraska - Lincoln. 


\title{
Evaluation of two perch deterrents for starlings, blackbirds and pigeons
}

\author{
THOMAS W. SEAMANS ${ }^{1}$, SCOTT C. BARRAS ${ }^{2}$, \& GLEN E. BERNHARDT ${ }^{1}$ \\ ${ }^{1}$ United States Department of Agriculture, Animal Plant Health Inspection Service, Wildlife Services, National Wildlife \\ Research Center, Ohio Field Station, Sandusky, OH, USA, and ${ }^{2}$ United States Department of Agriculture, Animal Plant \\ Health Inspection Service, Wildlife Services, National Wildlife Research Center, Mississippi Field Station, Mississippi State, \\ $M S, U S A$
}

\begin{abstract}
Bird-aircraft collisions are costly and potentially deadly to people and wildlife. From 1990 through 2004, 57702 bird collisions with aircraft were reported within the USA to the US Federal Aviation Administration. Approximately $82 \%$ of the strikes occur below $305 \mathrm{~m}$ height above ground level; therefore bird deterrents on airfields that reduce the quality of the birds' habitat are critical to safe airport operation. One management approach is to reduce perching sites within the airport premises. We tested two anti-perching devices (Birdwire ${ }^{\mathrm{TM}}$ and BirdBlox ${ }^{\mathrm{TM}}$ ) in an aviary setting. As an ancillary test, we determined which wire in a standard three-strand security array was preferred by blackbirds and starlings. Red-winged blackbirds (Agelaius phoeniceus), brown-headed cowbirds (Molothrus ater), and European starlings (Siurmus vulgaris) were deterred from sitting on a perch when anti-perching wire was installed $5 \mathrm{~cm}$ above the perch. These same species preferred the top wire of the three-wire security anay. Red-winged blackbirds, common grackles (Quiscalus quiscula), brown-headed cowbirds, European starlings, and rock pigeons (Columba livia) were deterred from perches protected by BirdBlox ${ }^{\mathrm{TM}}$. Because our tests were conducted in a captive situation, we recommend field testing the products to determine if bird use of aipport structures may be reduced in an operational setting.
\end{abstract}

Keywords: Agelaius phoeniceus, anti-perching, airports, BirdBlox ${ }^{T M}$, blackbirds, brown-headed cowbird, Columba livia, deterrent, common grackle, European starling, Molothrus ater, red-zinged blackbird, Quiscalus quiscula, rock pigeon, Sturnus vulgaris, wildlife strikes

\section{Introduction}

Bird-aircraft collisions (bird strikes) pose serious safety hazards to aircraft. From 1990 through all of 2004,57702 bird strikes with aircraft were reported to the US Federal Aviation Administration. These cost civil aviation at least $\$ 496$ million annually in the USA (Cleary et al. 2005). Approximately $82 \%$ of all bird strikes occurred below $305 \mathrm{~m}$ height (above ground level, AGL) and 93\% occurred below $914 \mathrm{~m} \mathrm{AGL}$ (Cleary et al. 2005; Dolbeer 2006). Eighty-one percent of bird strikes with damage reported to the aircraft occurred below $610 \mathrm{~m}$ AGL (Cleary et al. 2005). Concerns over airworthiness standards and high-speed departures of commercial aircraft in these zones of high bird activity (Dolbeer and Eschenfelder 2002; Dolbeer 2006) increase the need for sound management techniques that reduce birds' use of habitats in and around airports.

Due in part to their particular behavioural characteristics of flocking, blackbirds (Icterinae), European starlings (Sturnus vulgaris), and doves (Columbidae) are species of special concern at airports (Dolbeer et al. 1993, 2000; Cleary et al. 2005; Blackwell and Wright 2006). Effective anti-perching techniques are an important aspect of bird control in and around airports, buildings, walkways, signs, fences, carports and other like structures (Fitzwater 1994; Johnson and Glahn 1994). Blackbirds and starlings are commonly observed perching on airport structures or feeding in vegetation on airports but have been reported in only $4 \%$ of bird strikes resulting in damage (Cleary et al. 2005). However, there is an increasing trend of reported blackbird and starling strikes from 1990 to 2001 (Barras et al. 2002). Additionally, due to their large populations, flocking behaviours, and body density (Dolbeer and Stehn 1979; Seamans et al. 1995; Sauer et al. 2005) blackbirds and starlings have caused some of the most devastating aircraft accidents related to bird strikes in the USA (Cleary and Dolbeer 2005) and elsewhere (Thorpe 1996, 1998).

Birds perching on fences, signs, light fixtures and ledges are a problem at airports and other locations where these birds are not desired (see US Federal Aviation Administration 2004; Hazardous wildlife

Correspondence: Thomas W. Seamans, USDANWRC/OFS, 6100 Columbus Avenue, Sandusky, OH 44870-9660, USA. Fax: 14196258465. E-mail: thomas.w.seamans $a$ USDA.gov 
attractants on or near airports. Advisory Circular No: 150/5200-33A; Cleary and Dolbeer 2005). Large-scale killing of nuisance birds is often undesirable or impractical (Dolbeer 1986, 1998; Smith et al. 1999); thus, there is considerable demand for effective, non-lethal techniques to deter bird use of these sites. Reduction of perching sites should make airports less attractive to birds and thus reduce the risk of damaging bird strikes (Dolbeer 1984). Numerous harassment, management, and frightening techniques are available for reducing human-bird conflicts (Wright 1967; Feare and Swannack 1978; Good and Johnson 1978; Feare and Wadsworth 1981; Lyon and Caccamise 1981; Dolbeer 1984, 1994; Cleary 1994; Solman 1994; Dolbeer et al. 1995; Belant et al. 1998; Seamans et al. 2001, 2002; Blackwell et al. 2002; Avery and Genchi 2004, Seamans 2004). A perch exclusion that is often suggested is the placement of strands of wire or specialized pointed products (Lefebvre and Mott 1987; Johnson and Glahn 1994). Many of these suggested bird management tools have not been subjected to any formal scientific study, but are recommended due to incidental observations.

Overhead wires have been effective in keeping gulls (Larinae) (Amling 1980; Blokpoel and Tessier 1984; McLaren et al. 1984; Dolbeer et al. 1988; Steuber et al. 1995; Belant and Ickes 1996), Canada geese (Branta canadensis) (Fairizal 1992), and great cormorants (Phalacrocorax carbo sinensis) (Keller 1997; Schmidt 1998) from landing on water bodies, landfills, rooftops, and other broad expanses. This technique can be modified to include the placement of single or double strands of wire (Birdwire ${ }^{\mathrm{TM}}$, Bird Barrier America, Inc., Carson, CA, USA) across ledges, fence tops or other perching locations. However, no studies on the efficacy of these wires for different species or on variations of wire placement above perches have been published. Another antiperching device ( Birdblox ${ }^{\mathrm{TM}}$, Lena, IL, USA), a plastic form that fits over rafter lumber in pole buildings, either physically blocks space or presents a row of sharp points that have minimal surface area for perching. No studies on the efficacy of this product have been published. Additionally, knowledge of where birds prefer to perch is important so that antiperching devices may be placed in preferred perch locations. No studies were found that quantitatively demonstrated perch preference on three-strand security arrays. We replicated artificial perches in a captive setting to evaluate the perch preference and the efficacy of Birdwire ${ }^{T M}$ and Birdblox ${ }^{T M}$ exclusion devices on different species of birds.

\section{Methods}

Our studies were conducted in 2001 and 2002 at the US Department of Agriculture's, Wildlife Services, National Wildlife Research Center, Ohio Field Station at National Aeronautical Space Administra- tion Plum Brook Station (PBS), Erie County, Ohio, USA ( $\left.41^{\circ} 27^{\prime} \mathrm{N}, 82^{\circ} 42^{\prime} \mathrm{W}\right)$. PBS is a 2200 -ha fenced facility with large tracts of open, fallow fields, interspersed with woodlots, and surrounded by agricultural fields.

\subsection{Anti-perching wire}

We conducted each of three different experiments (perch height, two-choice, and wire array) in 2001 using brown-headed cowbirds (Molothrus ater), European starlings, and red-winged blackbirds (Agelaius phoeniceus). These birds were live-trapped using decoy traps (Dolbeer 1994). They were attracted to the traps using a white millet/sunflower seed bait mixture and captive cowbirds as decoys. Birds were housed at an outdoor aviary at PBS (Woronecki et al. 1988). The aviary consisted of a netted, roofed pavilion $(12.6 \times 6.6 \mathrm{~m})$ containing two $2.4 \times 2.4 \times 1.9-\mathrm{m}$ holding pens. The birds were fed a mixture of millet and sunflower seeds and supplemented with commercial turkey ration. Birds were fed and given fresh water daily.

Experiments were conducted in $24,0.5 \times 1.0 \times$ 1.9-m cages, suspended from the ceiling of the aviary. Perches used in this evaluation were constructed of barbless wire 1.9-m long of identical gauge (12-gauge) and design as that used on security fences. Barbless wire was used to reduce the risk of injury and undue pain to experimental subjects. The exclusion device was a commercial product called Birdwire ${ }^{\text {TM }}$ exclusion system. This system consists of $0.7-\mathrm{mm}$ nylon-coated stainless steel wire elevated above the area to be protected by posts of varying heights.

After setting up the perches, one bird was assigned to each cage at least $24-\mathrm{h}$ prior to the initiation of experiments to allow the bird to acclimate to the cage. Two blinds were established about $10 \mathrm{~m}$ from either side of the aviary. An observer in a blind conducted a spot count of each cage once every $3 \mathrm{~min}$ for $1 \mathrm{~h}(20$ observations/cage per $h$ ) and recorded where the bird was in the cage at the instant of the observation. These observations were conducted twice daily, at 10:00 and 14:00 $\mathrm{h}$, using the same procedure.

2.1.1. Perch height experiment. To determine the appropriate height for use of exclusion wires over perches in this study, we presented each bird with a single perch and varied the height of the exclusion wire above that perch. Perch height experiments were conducted with brown-headed cowbirds on 811 May 2001, red-winged blackbirds on $11-19$ April 2001, and with European starlings on 22-26 October 2001. The exclusion wire was first established $10-15 \mathrm{~cm}$ above the perch, depending upon the perching height of the species evaluated. The wire was lowered by $2.5 \mathrm{~cm}$ on successive days using the same birds in each of five or six successive tests until the exclusion wire was $2.5 \mathrm{~cm}$ above the perch. We plotted bird use of perches under each exclusion height to determine graphically the height at which 
perch use was lowest. We used a paired $t$-test to determine if there were differences in perch use (Cody and Smith 1991). A Wilcoxon signed ranks tests was used in cases where data were not distributed normally (Zar 1984).

2.1.2. Two-choice experiment. The two-choice experiments were conducted with brown-headed cowbirds on 16-18 May 2001, red-winged blackbirds on 24-26 April 2001, and with European starlings on 30 October -1 November 2001 . We established two 1.9-m perches such that the perches were about $0.4 \mathrm{~m}$ apart in each of 24 cages (described above). One perch per cage was randomly selected to have an exclusion wire placed above the perch at a height determined to best exclude the species involved during the wire height test. We conducted observations twice per day for three consecutive days to determine if the birds chose or avoided the perch treated with the exclusion wire. We used a paired $t$ test to determine if there were differences in perch use (Cody and Smith 1991). A Wilcoxon signed ranks tests was used in cases where data were not distributed normally (Zar 1984).

2.1.3. Wire array experiment. We conducted aviary tests to determine if birds preferentially used individual strands of barbed wire in standard three-strand arrays atop security fences, depending upon the location of the wire in the array. The three-wire experiments were conducted with brown-headed cowbirds on 23-25 May 2001, red-winged blackbirds on 3-5 April 2001, and with European starlings on $9-11$ October 2001 . We replicated the angle $\left(40^{\circ}\right)$ and spacing $(13 \mathrm{~cm})$ of wires from a standard security fence design within each of 24 experimental cages described above. We then placed one bird in each cage and conducted observations twice per day for three consecutive days. To determine whether the birds showed a preference for any perch, we compared the number of observations of birds on each strand. We compared bird use of the three strands using a Kruskall - Wallis test because data did not meet the assumption for normality under requirements of parametric tests (Zar 1984).

\subsection{BirdBlox ${ }^{T M}$}

Brown-headed cowbirds, red-winged blackbirds, common grackles (Quiscalus quiscula), and rock pigeons (Columba livia) were captured in April 2002, and European starlings were captured in October 2002 in northern Ohio using decoy and walk-in traps. All birds were held and fed in two $2.4 \times 2.4 \times 1.9-\mathrm{m}$ cages as described above. Experiments were conducted in the $20,0.5 \times 1.0 \times 1.9-\mathrm{m}$ cages described above.

2.2.1. Two-choice experiment. We established two parallel, $1.9-\mathrm{m}$ perches in each of the 20 experi- mental cages such that perches were about $0.4 \mathrm{~m}$ apart. One perch consisted of BirdBlox ${ }^{T M}$ covering the $5-\mathrm{cm}$ side of a $1.9-\mathrm{m}, 5 \times 10-\mathrm{cm}$ board. The second perch was constructed of barbless wire of identical gauge (12-gauge) and design as that used on security fences. Birds readily perch on the wire (see results of anti-perching wire), and because it provided the only other perch it was considered an acceptable alternative perch. After placing the perches, one bird was placed into each cage 24-h before observations began to allow the bird to acclimate to the cage.

Observations were conducted from a vehicle $10 \mathrm{~m}$ from the experimental cages. An observer in the vehicle conducted a spot count of each cage once every $3 \mathrm{~min}$ for $1 \mathrm{~h}$ (20 observations/cage per h). These observations were conducted twice daily, for 4-5 days, at 10:00 and 14:00 h. Data recorded were the location of the bird at the moment of observation.

2.2.2. No-choice experiment. At the conclusion of the two-choice experiment, the barbless wire was removed from each cage. The bird from the two-choice experiment was left in the cage because it was habituated to that cage. Observations were started $72 \mathrm{~h}$ later and were conducted as in the two-choice experiment for 3-4 days.

Due to the magnitude of difference between counts of birds using the BirdBlox ${ }^{\text {TM }}$ perch and either the other perch or rest of the cage, statistical tests were not conducted. Descriptive statistics are provided.

\section{Results}

\subsection{Anti-perching wire}

3.1.1. Perch height experiment. Perch use generally decreased with decreasing height of the exclusion wire for all three species (Figure 1). For all three species, perch use appeared to reach a lowest asymptote at $5 \mathrm{~cm}$, and actually approached zero use for redwinged blackbirds and starlings. Therefore, we selected $5 \mathrm{~cm}$ as the exclusion height to be used for all three species in the two-choice experiment.

3.1.2. Two-choice experiment. Perch use by redwinged blackbirds $(5.30 \leq t \leq 6.98$, df $=23, P<0.01)$, brown-headed cowbirds $(7.69 \leq t \leq 9.08, \mathrm{df}=23, P<$ 0.01 ), and European starlings $(33 \leq t \leq 60$, df $=23$, $P<0.01$ ) was nearly eliminated in each of the three daily experiments for each species by the exclusion wire in the two-choice test (Figure 2). Brown-headed cowbirds were observed on the excluded perch only $2.4 \%$ (69 of 2880 observations) of the time compared to $46.7 \%$ of time ( 1345 observations) spent on control perches. Red-winged blackbirds were observed on the excluded perch only $1.6 \%$ (46 of 2880 observations) of the time compared to $39.8 \%$ of time (1147 observations) 


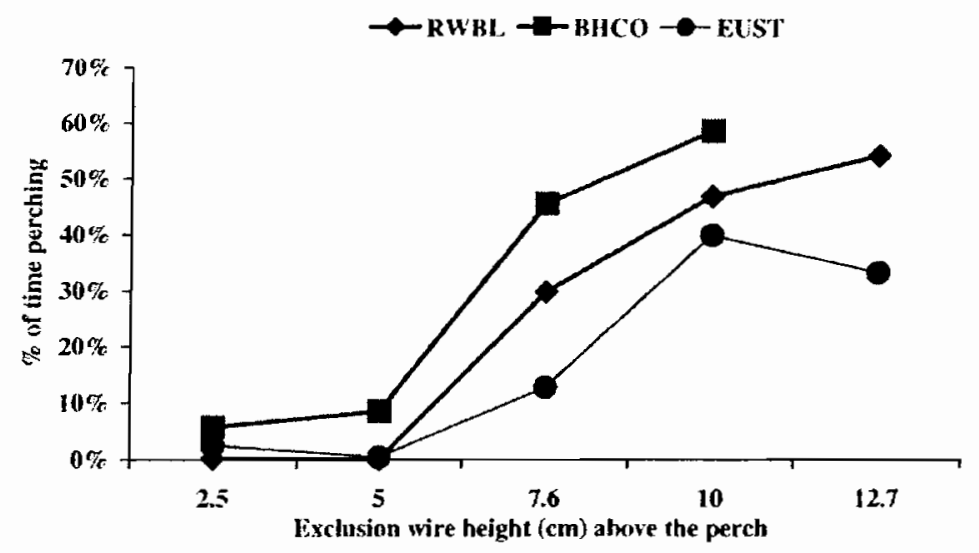

Figure 1. Percent of observations periods when brown-headed cowbirds (BHCO), European starlings (EUST), and red-winged blackbirds (RWBL) were observed using a single perch with an exclusion wire mounted at different heights above the perch.

spent on control perches. European starlings were observed on the excluded perch only $0.1 \%$ (three of 2880 observations) of the time compared to $14.0 \%$ of time (402 observations) spent on control perches.

3.1.3. Wire array experiment. Use of top, middle, and bottom strands of the fence array differed for red-winged blackbirds $\left(49.61 \leq \chi^{2} \leq 51.30, \mathrm{df}=2\right.$, 23, $P<0.01$ ), brown-headed cowbirds $(42.73 \leq$ $\left.\chi^{2} \leq 49.92, \mathrm{df}=2,23, P<0.01\right)$, and European starlings $\left(17.22 \leq \chi^{2} \leq 51.58, \mathrm{df}=2,23, P<0.01\right)$ in each of the three daily experiments (Figure 3 ). Individuals of all three species overwhelmingly used the top wire during most observations that involved perched behaviour. Of the 1333 observations (out of 2880 total) where brown-headed cowbirds were observed to be perching on one of the three wires, $88 \%$ (1177) were on the top wire, $5 \%$ (67) on the middle wire and $7 \%(89)$ on the bottom wire. For red-winged blackbirds, $92 \%$ (1591), 5\% (94), and $3 \%$ (48) of the 1733 perching observations were on the top, middle, and bottom wire, respectively. For European starlings, $87 \%$ (766), $8 \%(70)$, and 5\% (42) of the 878 perching observations were on the top, middle, and bottom wire, respectively.

\subsection{BirdBlox ${ }^{T M}$}

3.2.1. Two-choice experiment. European starlings, red-winged blackbirds, and common grackles were observed on BirdBlox ${ }^{\mathrm{TM}}$ in only 21,5 and 1 of the 17600 spot counts, respectively. Brown-headed cowbirds and rock pigeons were not observed on Birdblox $^{T M}$. In contrast to the Birdblox ${ }^{\mathrm{TM}}$, birds were observed on the unprotected perch in 2482 $(14.1 \%)$ of the counts (Figure 4).

3.2.2. No-choice experiment. We conducted a total of 15480 spot counts. Red-winged blackbirds were observed on Birdblox ${ }^{\mathrm{TM}}$ only 22 times and European starlings three times. Common grackles,

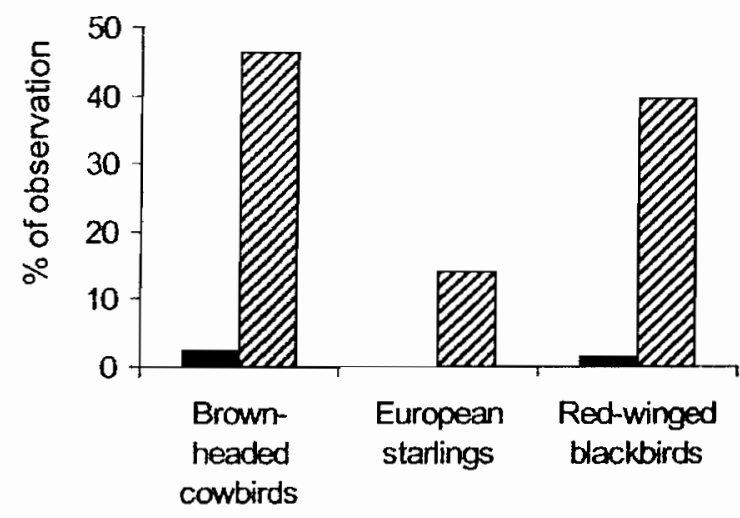

\section{Excluded $\square$ Control}

Figure 2. Percent of observations (2880 observations for each species) when birds were observed using either a perch with an exclusion wire mounted at $5 \mathrm{~cm}$ above the perch or a second (control) perch without an exclusion wire. Differences were statistically significant $(P<0.01)$.

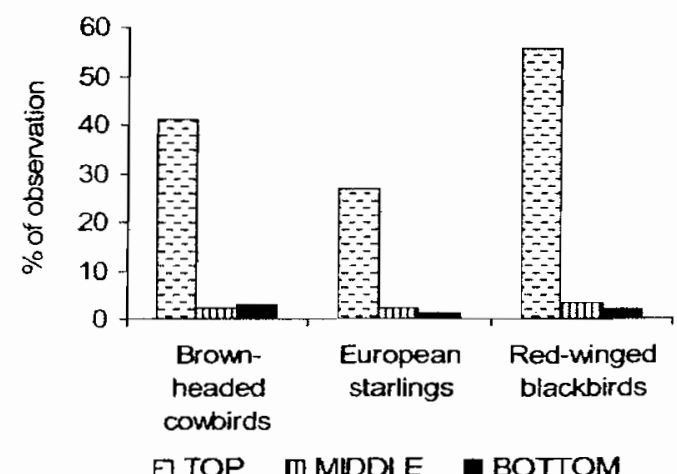

Figure 3. Percent of observations (2880 observations) when birds were observed using either the top, middle, or bottom wire on a simulated fence-top array. Use of the top wire was greater $(P<0.01)$ than use of the others. 
brown-headed cowbirds, and rock pigeons were not observed on Birdblox $^{\text {TM }}$ (Figure 5).

\section{Discussion}

We found anti-perching wire and BirdBlox ${ }^{\mathrm{TM}}$ to be effective perching deterrents when tested in an aviary setting. The height at which bird wire excluded blackbirds and starlings most effectively from simulated fence perches $(5 \mathrm{~cm})$ is probably a function of the size of the birds and their perching posture. At $5 \mathrm{~cm}$, we observed the exclusion wire to contact the lower abdomen of birds that attempted to land on perches. This contact may have been uncomfortable

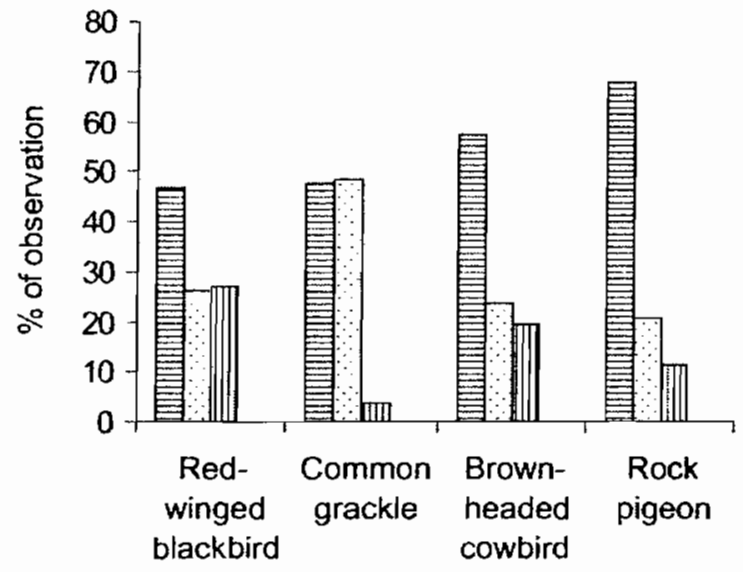

\section{日 FLOOR $\square$ OTHER 四PERCH $\square$ BIRDBLOX}

Figure 4. Percent of observations of birds using a perch protected by Birdblox $^{\mathrm{TM}}$, an unprotected perch, the cage floor or some other area of a cage (two-choice test).

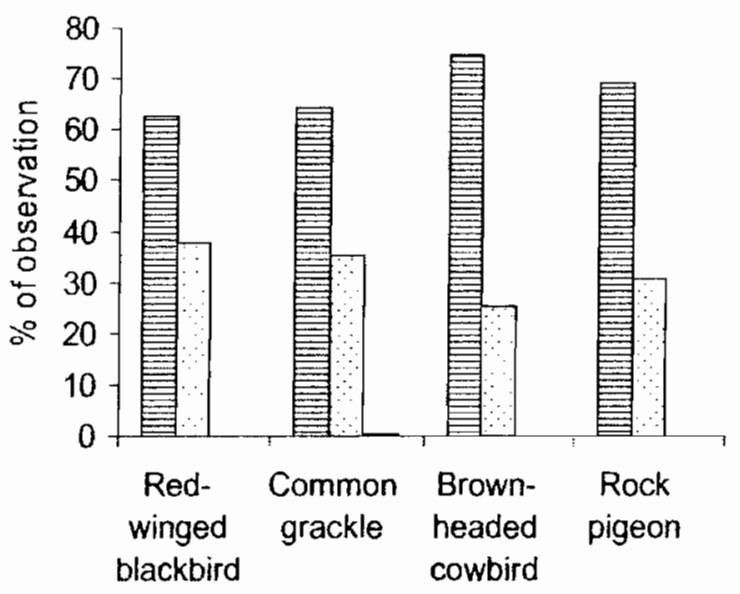

\section{G FLOOR $\square$ OTHER a BIRDBLOX}

Figure 5. Percent of observations of birds using a perch protected by Birdblox ${ }^{1 \mathrm{M}}$, the cage floor or some other area of a cage (no-choice test). or prevented the birds from assuming a normal posture. The upper height at which exclusion first began to occur was probably dictated by the same factors. Although exclusion was overwhelmingly effective at $5 \mathrm{~cm}$, all species tested were approximately the same size, and the effective exclusion height may be different for larger birds.

Birds may have preferred the highest perch in the three-strand experiment because it provided an enhanced view of their surroundings or a better singing and display post without interference from wires higher than head level (Stokes 1979; Feare 1984; Beletsky 1996). This advantage may have been especially important for red-winged blackbirds and brown-headed cowbirds, which were evaluated during their breeding seasons. Although the responses for European starlings were similar in partern to those of red-winged blackbirds and brown-headed cowbirds, starlings spent relatively little time on the perches. These birds use many habitats and spend a great deal of time on the ground on airfields (Feare 1984; Thorpe 1998) while foraging for insects.

In aviary tests, Birdblox ${ }^{\mathrm{TM}}$ was effective at keeping five species of common pest birds from perching on a desired perch. Red-winged blackbirds and European starlings showed the greatest ability to use the perches. However, even in the rare instances when birds chose to sit on a Birdblox ${ }^{\mathrm{TM}}$ perch, the time was momentary. We never observed a bird to sit for more than $5 \mathrm{~s}$ on a Birdblox ${ }^{\mathrm{TM}}$ protected perch, an observation commonly made on the untreated perch.

Each experiment described above was limited to aviary conditions. However, because the devices showed dramatic reductions in perching with all four species tested in no- and two-choice tests, we believe that the products will reduce perching. We recommend field testing of the products to confirm our aviary studies.

\section{Acknowledgements}

This study was supported in part by the Federal Aviation Administration (FAA). Opinions expressed in these studies do not necessarily reflect current FAA policy decisions governing the control of wildlife on or near airports. We especially thank R. Dolbeer for his interest and suggestions regarding this study, and L. Brohl, R. Bush, J. Cepek, Z. Patton, and $R$. White for field support. B. Poggialli provided valuable field and logistical assistance.

\section{Notes}

Mention of companies or commercial products does not imply recommendation or endorsement by the US Department of Agriculture over others not mentioned. The US Department of Agriculture neither guarantees nor warrants the standard of any product mentioned. Product names are mentioned here solely to report factually on available data and to provide specific information. The National Wildlife Research Center Animal Care and Use Committee approved procedures before the start of the study. 


\section{References}

Amling W. 1980. Exclusion of gulls from reservoirs in Orange County, Califomia. In: Clark JP, Marsh RE, editors. Proceedings of the Ninth Vertebrate Pest Conference; 1980 March 4-6; Fresno, CA. Davis, CA: University of California. pp 29-30.

Avery ML, Genchi AC. 2004. Avian perching deterrents on ultrasonic sensors at airport wind-shear alert systems. Wildhife Society Bulletin 32:718-725.

Barras SC, Wright SE, Seamans TW. 2002. Blackbird and starling strikes to civil aircraft, 1990-2001. In: Paulik L, editor. Proceedings of a special symposium of The Wildlife Society on Management of North American Blackbirds, 27 September 2002, Bismarck, North Dakota. Fort Collins, Colorado: The National Wildlife Research Center. pp 91-96.

Belant J, Ickes SK 1996. Overhead wires reduce roof-nesting by ring-billed gulls and herring gulls. In: Timm RM, Crabb AC, editors. Proceedings of the Seventh Vertebrate Pest Conference, 5-7 March 1996, Rohnert Park, CA. Davis, CA: University of California. pp 108-112.

Belant $\pi$, Woronecki PP, Dolbeer RA, Seamans TW. 1998. Ineffectiveness of five commercial deterrents for nesting starlings. Wildlife Society Bulletin 26:264-268.

Beletsky L. 1996. The red-winged blackbird. The biology of a strongly polygynous songbird. London: Academic Press Limited.

Blackwell BF, Bemhardt GE, Dolbeer RA. 2002. Lasers as nonlethal avian repellents. Journal of Wildife Management 66: 250-258.

Blackwell BF, Wright SE. 2006. Collisions of red-tailed hawks (Buteo jamaicensis), turkey vulture (Cathartes aura), and black vultures (Coragyps atratus) with aircraft: Implications for birdstrike reduction. Journal of Raptor Research 40:76-80.

Blockpoel H, Tessier GD. 1984. Overhead wires and monofilament lines exclude ring-billed gulls from public places. Wildlife Society Bulletin 55:55-58.

Cleary EC. 1994. Waterfowl. In: Hyngstrom SE, Timm RM, Larson GE, editors. Prevention and control of wildlife damage. University of Nebraska Cooperative Extension Service, Lincoln, Nebraska, USA. pp E139-155.

Cleary EC, Dolbeer RA. 2005. Wildlife hazard management at airports: a manual for airport personnel. 2nd ed. Federal Aviation Administration, Office of Airport Safety and Standards, Washington, DC, USA. p 348.

Cleary EC, Wright SE, Dolbeer RA. 2005. Wildlife strikes to civilian aircraft in the United States, 1990-2004. Federal Aviation Administration, Wildlife Aircraft Strike Database Serial Report 11.

Cody RP, Smith JK. 1991. Applied statistics and the SAS programming language, 3rd ed. Englewood Cliffs, NJ: Prentice Hall.

Dolbeer RA. 1986. Current status and potential of lethal means of reducing bird damage in agriculture. International Ornithological Congress 19:474-483.

Doibeer RA. 1984. Blackbirds and starlings: Population ecology and habits related to airpor environments. In: Harrison MJ, Gauthreaux SA Jr, Abron-Robison LA, editors. Proceedings of the Wildlife Hazards to Aircraft Conference and Training Workshop, 22-25 May 1984, Charleston, South Carolina. US Department of Transportation, Federal Aviation Administration, Office of Airport Standards, Washington, DC (DOT/FAAAAS 84-1).

Dolbeer RA. 1994. Blackbirds. In: Hyngstrom SE, Timm RM, Larson GE, editors. Prevention and control of wildlife damage. Lincoln, Nebraska, USA: University of Nebraska Cooperative Extension Service. pp E25-32.

Dolbeer RA. 1998. Population dynamics: the foundation of wildlife damage management for the 21 st Century. In: Baker $\mathrm{RO}$, Crabb AC, editors. Proceedings of the Eighteenth Vertebrate Pest Conference, 2-5 March 1998, Costa Mesa, CA. Davis, CA: University of California. pp 2-11.

Dolbeer RA. 2006. Height distribution of birds recorded by collisions with civil aircraft. Journal of Wildlife Management (in press).
Dolbeer RA, Stehn RA. 1979: Population trends of blackbirds and starlings in North America, 1966-1976. US Department of Interior, Fish and Wildlife Service, Special Scientific Report Wildlife Number 214. p 99.

Dolbeer RA, Woronecki PP, Cleary EC, Butler EB. 1988. Site evaluation of gull exclusion device at Fresh Kill landfill, Staten Island, New York. Denver Wildlife Research Center, Bird Damage Research Report 411.

Dolbeer RA, Belant $\pi$, Sillings J. 1993. Shooting gulls reduces strikes with airport at John F. Kennedy International Aircraft. Wildlife Society Bulletin 21:442-450.

Dolbeer RA, Holler NR, Hawthome DW. 1995. Identification and control of wildlife damage. In: Bookhout TA, editor. Research and management techniques for wildlife and habitats. Bethesda, MD: The Wildlife Society. pp 474-506.

Dolbeer RA, Wright SE, Cleary EC. 2000. Ranking the hazard level of wildlife species to aviation using the National Wildlife Strike Database. Wildlife Society Bulletin 28:372-378.

Dolbeer RA, Eschenfelder P. 2002. Population increases of large birds, airworthiness standards and high-speed flight: a precarious combination. In: Lacagnina $M$, Rosenkrans W, Werfelman $\mathrm{L}$ ) editors. Proceedings of the 55th International Air Safety Seminar, 4-7 November 2002, Dublin, Ireland. Alexandria, Virginia: Flight Safety Foundation. pp 273-281.

Fairaizl SD. 1992. An integrated approach to the management of urban Canada goose depredations. In: Borreco JE, Marsh RE, editors. Proceedings of the Fifteenth Vertebrate Pest Conference, 3-5 March 1992, Newport Beach, CA. Davis, CA: University of California. pp 105-109.

Feare C. 1984. The starling. Oxford: Oxford University Press.

Feare CJ, Swannack KP. 1978. Starling damage and its prevention at an open-fronted calf yard. Animal Production 26:259-265.

Feare CJ, Wadsworth TJ. 1981. Starling damage on farms using the complete diet system of feeding dairy cows. Animal Production 32:179-183.

Fitzwater WD. 1994. House sparrows. In: Hyngstrom SE, Timm RM, Larson GE, editors. Prevention and control of wildlife damage. Lincoln, NE: University of Nebraska Cooperative Extension Service, pp E101-108.

Good HB, Johnson DM. 1978. Non-lethal blackbird roost control. Pest Control 46:14-18

Johnson RJ, Glahn JF. 1994. Starlings. In: Hyngstrom SE, Timm RM, Larson GE, editors. Prevention and control of wildlife damage. Lincoln, NE: University of Nebraska Cooperative Extension Service. pp E109-120.

Keller T. 1997. Habitat management as a tool to reduce depredation by fish-eating birds [abstract]. In: Proceedings of the First European Vertebrate Pest Management Conference; September 1997, Sand Hutton, United Kingdom. Sand Hutton: Central Science Laboratory. p 35.

Lefebvre PW, Mott DF. 1987. Reducing birdaircraft hazards at airports through control of bird nesting, roosting, perching, and feeding. US Fish and Wildlife Service, Denver Wildlife Research Center, Bird Damage Research Report 390. p 90.

Lyon LA, Caccamise DF. 1981. Habitat selection by roosting blackbirds and starlings: management implications. Journal of Wildlife Management 45:435-443.

McLaren MA, Harris RE, Richardson WJ. 1984. Effectiveness of an overhead wirebarrier in deterring gulls from feeding at a sanitary landfill. In: Harrison MJ, Gauthreaux SA Jr, Abron-Robinson LA, editors. Proceedings of the Wildlife Hazards to Aircraft Conference and Training Workshop, 22-25 May 1984, Charleston, South Carolina. Washington, DC: US Department of Transportation, Federal Aviation Administration. pp 241-251

Sauer JR, Hines JE, Fallon J. 2005. The North American breeding bird survey, results and analysis 1966-2004. Version 2005.2, USGS Patuxent Wildlife Research Center, Laurel, Maryland.

Schmidt JP. 1998. Deterring cormorants Phalacrocorax carbo sinensis with wide spaced overhead wire grids at common carp Cyprinus carpio wintering ponds in the Bavarian Oberpfalz, 1995-1 996. Wetlands International Cormorant Research Group Bulletin 3:16-21 
Seamans TW. 2004. Response of roosting turkey vultures to a vulture effigy. Ohio Journal of Science 104:136-138.

Seamans TW, Hammershock DW, Bernhardt GE. 1995. Determination of body density for twelve bird species. Ibis 137: 424-428.

Seamans TW, Lovell CD, Dolbeer RA, Cepek JD. 2001. Evaluation of mirrors to deter nesting starlings. Wildlife Society Bulletin 29:1061-1066.

Seamans TW, Blackwell BF, Gansowski JT. 2002. Evaluation of the Allsopp Helikite ${ }^{\text {i: }}$ as a bird scaring device. In: Timm RM, Schmidt RH, editors. Proceedings of the Twentieth Vertebrate Pest Conference, 4-7 March 2002, Reno, NV. Davis, CA: University of Califomia. pp 129-134.

Smith AE, Craven SR, Curtis PD. 1999. Managing Canada geese in urban environments. Jack Berryman Institution Publication 16, and Comell University Cooperative Extension, Ithaca, New York, USA.

Solman VEF. 1994. Gulls. In: Hyngstrom SE, Timm RM, Larson GE, editors. Prevention and control of wildlife damage. Lincoln, NE: University of Nebraska Cooperative Extension Service. pp E49-52.

Steuber JE, Pitzler ME, Oldenburg JG. 1995. Protecting juvenile salmonids from gull predation using wire exclusion below hydroelectric dams. In: Masters RE, Huggins JG, editors. Proceedings of the Twelfth Great Plains Wildlife Damage Control Workshop, 1980. Ardmore, OK: Noble Foundation. pp 38-41.
Stokes DW. 1979. A guide to the behavior of common birds. Boston, MA: Little, Brown and Company.

Thorpe J. 1996. Fatalities and destroyed civil airctaft due to bird strikes, 1912-1995. In: Proceedings of Bird Strike Committee Europe 23, 13-17 May 1996. London. pp 17-32.

Thorpe J. 1998. The implications of recent bird strike accidents and multiple engine ingestions. In: Proceedings of Bird Strike Committee Europe 24, 14-18 September 1998, Stará Lesná, Slovakia. pp 11-22.

Woronecki PP, Dolbeer RA, Otis DL. 1988. Evaluating corn varieties for resistance to damage by blackbirds and starlings. In: Shumake SA, Bullard RW, editors. Vertebrate Pest Control and Management Materials. Vol. 5. Philadelphia, PA: Amenican Society for Testing and Materials. pp 27-38.

Wright EN. 1967. Modification of the habitat as a means of bird control. In: Murton RK, Wright EN, editors. The problems of birds as pests. Symposia for the Institute of Biology, no. 17. London: Academic Press. pp 97-116.

Zar JH. 1984. Biostatistical analysis. Paired-sample hypotheses. Englewood Cliffs, NJ: Prentice-Hall. pp 150-161. 
This article was downloaded by:[Seamans, Thomas]

On: 24 January 2007

Access Defails: [subscription number 768157657]

Publisher: Taylor \& Francis

Informa Ltd Registered in England and Wales Registered Number: 1072954

Registered office: Mortimer House, 37-41 Mortimer Street, London W1T 3JH, UK

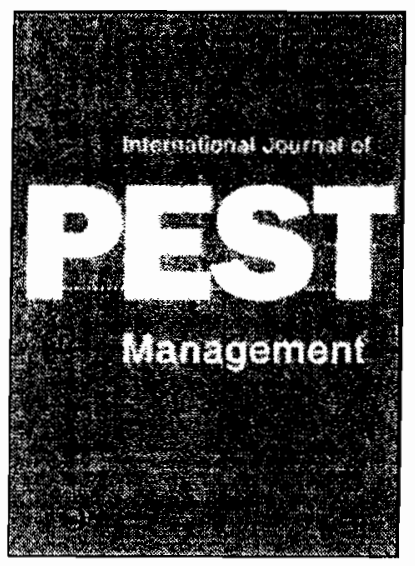

\section{International Journal of Pest Management}

Publication details, including instructions for authors and subscription information: http://www. informaworld.com/smpp/title-content=1713797655

Evaluation of two perch deterrents for starlings, blackbirds and pigeons

To link to this article: DOI: $10.1080 / 09670870601058890$

URL: http://dx.doi.org/10.1080/09670870601058890

Full terms and conditions of use: $h$ ttp://wuw. informaworld.com/terms-and-conditions-of-access.pdf

This article maybe used for research, teaching and private study purposes. Any substantial or systematic reproduction, re-distribution, re-selling, loan or sub-licensing, systematic supply or distribution in any form to anyone is expressly forbidden.

The publisher does not give any warranty express or implied or make any representation that the contents will be complete or accurate or up to date. The accuracy of any instructions, formulae and drug doses should be independently verified with primary sources. The publisher shall not be liable for any loss, actions, claims, proceedings, demand or costs or damages whatsoever or howsoever caused arising directly or indirectly in connection with or arising out of the use of this material.

(C) Taylor and Francis 2007 